\title{
Pemberesan Harta Pailit Debitor Yang Menjadi Objek Sita Pada Perkara Pidana (Studi Kasus Perkara NO. 11/PDT.SUS-GUGATAN LAIN- LAIN/2018/PN.JKT.PST)
}

\author{
Dani Triardi \\ Magister Ilmu Hukum Ekonomi, Universitas Indonesia \\ Email Korespondensi: danitriardi@gmail.com
}

\begin{abstract}
Abstrak. Bukan tidak mungkin suatu subjek hukum perorangan atau badan yang sedang dalam proses kepailitan, diproses secara bersamaan dengan perkara pidana. Hal ini menimbulkan adanya kemungkinan bahwa harta debitor pailit dalam proses kepailitan yang seharusnya menjadi dalam penguasaan Kurator, juga menjadi objek sita dalam perkara pidana. Namun peraturan perundang-undangan belum mengakomodir ketentuan secara eksplisit mengenai prosedur penyitaan dan penguasaan harta debitor pailit dalam hal terjadi tumpang tindih kewenangan antara Kurator dalam proses kepailitan dan Penuntut Umum dalam proses perkara pidana. Tujuan penelitian ini adalah untuk mengetahui prosedur pemberesan harta debitor pailit yang secara bersamaan menjadi objek sita barang bukti oleh Kejaksaan/Penuntut Umum untuk keperluan perkara pidana berdasarkan peraturan perundang-undangan atau asas hukum yang berlaku. Metode Penelitian yang digunakan adalah normatif, dengan menggunakan data sekunder yang diperoleh dari penelitian kepustakaan antara lain sumber hukum primer, sekunder dan tersier. Dalam hal terjadi kondisi dimana harta debitor pailit dalam proses kepailitan menjadi objek sita oleh dalam perkara pidana di waktu yang bersamaan, maka yang harus didahulukan adalah proses hukum yang sudah terlebih dahulu memiliki kekuatan hukum tetap. Apabila putusan pailit terjadi lebih dahulu, maka penguasaan harta debitor akan tetap menjadi wewenang kurator untuk dilakukan pemberesan utang. Namun Penuntut Umum tetap tidak dapat membebankan sita umum untuk negara terhadap bukti berupa harta terdakwa yang merupakan debitor pailit karena harta tersebut merupakan hak dari para kreditor.
\end{abstract}

Kata Kunci: Kepailitan, Aset, Kurator, Sita Umum.

Abstract. It is not impossible for legal subject such as an individual or entity that is in the process of bankruptcy, to be processed simultaneously with a criminal case. This raises the possibility that the assets of the bankrupt debtor in the bankruptcy process, which should be under the control of the Curator, will also be the object of confiscation in a criminal case. However, the laws and regulations have not explicitly accommodated the procedures for confiscating and controlling the assets of the bankrupt debtor in the event that there is an overlap of authority between the Curator in the bankruptcy process and the Public Prosecutor in the criminal case process. The purpose of this study is to determine the procedure for settlement of bankrupt debtor assets which simultaneously becomes the object of confiscation of evidence by the Prosecutor for the purposes of a criminal case based on prevailing statutory regulations or legal principles. The research method used is normative, using secondary data, which is obtained from literature research, including primary, secondary and tertiary sources of law. In the event of a condition where the assets of the bankrupt debtor in the bankruptcy process become the object of confiscation in a criminal case at the same time, what must take precedence is a legal process that already has permanent legal force first. If the bankruptcy decision occurs earlier, then control of the debtor's assets will remain under the curator's authority to settle the debt. However, the Public Prosecutor is still unable to impose general confiscation for the state on evidence in the form of assets of a defendant who is a bankrupt debtor, because such assets are entitled to the creditors.

Keywords: Bankruptcy, Asset, Curator, Confiscation.

\section{PENDAHULUAN}

Kepailitan adalah suatu proses hukum yang dilakukan melalui permohonan pernyataan kepada Pengadilan untuk menyatakan bahwa suatu subjek berupa individu atau badan yang merupakan debitor dinyatakan pailit (tidak mampu membayar utangnya). Pernyataan pailit oleh Pengadilan memberikan akibat hukum kepada individu atau badan yang dinyatakan pailit tersebut berupa disitanya seluruh harta kekayaannya selaku debitor, untuk dilakukan pemberesan/penyelesaian utang oleh kurator kepada para kreditor dari debitor pailit.

Harta kekayaan atau aset debitor dalam suatu proses kepailitan memiliki fungsi penting sebagai sumber pembayaran dan penyelesaian utang debitor pailit kepada para kreditornya, sehingga hak kreditor dalam menerima pembayaran atas utang terpenuhi meskipun terkadang jumlahnya tidak sesuai dengan jumlah pembayaran utang yang harus 
diterimanya. Mengingat pentingnya harta kekayaan debitor dalam proses kepailitan, Undang-Undang Nomor 37 Tahun 2004 tentang Kepailitan dan Penundaan Kewajiban Pembayaran Utang ("UU Kepailitan dan PKPU") telah mengakomodasi ketentuan mengenai pengurusan atas harta kekayaan debitor yang mengalami pailit. Debitor akan kehilangan haknya untuk menguasai dan mengurus hartanya, sejak suatu debitor dinyatakan pailit berdasarkan putusan pailit oleh Pengadilan Niaga, sehingga harta tersebut akan diambilalih untuk dilakukan pengurusan oleh Kurator. Dalam perkara kepailitan Kurator harus menguasai harta kekayaan debitor agar dirinya dapat melakukan pemberesan dengan mentransformasi harta kekayaan tersebut menjadi uang yang dapat dibayarkan secara adil kepada para kreditor.

Bukan tidak mungkin suatu subjek hukum perorangan atau badan yang sedang dalam proses kepailitan, diproses secara bersamaan dengan perkara pidana. Hal tersebut terjadi pada kasus penipuan berkedok investasi yang dilakukan Koperasi Simpan Pinjam Pandawa Mandiri ("Koperasi Pandawa"). Koperasi Pandawa mulai beroperasi 2015 sebagai koperasi simpan pinjam dan menghimpun dana dari masyarakat dengan menjanjikan keuntungan $10 \%$ setiap bulan kepada para nasabahnya, namun di tengah jalan Koperasi Pandawa tidak dapat memberikan keuntungan yang dijanjikan kepada para nasabahnya seperti yang pada bulan sebelumnya mereka lakukan. Para nasabah yang mulai mencurigai kelangsungan usaha Koperasi Pandawa, kemudian menuntut penarikan dananya pada Koperasi Pandawa, namun Koperasi Pandawa tidak dapat mengembalikan dana milik nasabahnya tersebut. Pada awalnya salah satu nasabah melaporkan Koperasi Pandawa kepada pihak kepolisian atas dasar penipuan karena dianggap melanggar ketentuan Pasal 378 KUHP. Koperasi Pandawa dinilai memenuhi unsur penipuan dalam ketentuan pidana setelah dirinya membawa kabur uang ribuan masyarakat selaku investor dengan total triliunan rupiah. Mengingat bentuk badan Koperasi Pandawa adalah koperasi simpan pinjam, maka pihak kepolisian berkoordinasi dengan Otoritas Jasa Keuangan untuk menentukan jenis pelanggaran yang dilakukan oleh Koperasi Pandawa. Seiring dengan berjalannya penyelidikan, penyidikan dan penuntutan, didapati bahwa Koperasi Pandawa melanggar ketentuan pidana karena menjalankan kegiatan usaha penghimpunan dana tanpa izin usaha. Mengingat para korban menginginkan agar uangnya kembali, maka diajukan permohonan pailit kepada Koperasi Pandawa agar korban dapat menerima pengembalian uang yang didapatkan dari harta kekayaan Koperasi Pandawa.

Pada Desember 2017, Pengadilan Negeri (PN) Depok menyatakan bahwa para pengurus Koperasi Pandawa bersalah melakukan kejahatan perbankan dan oleh karenanya para pengurus Koperasi Pandawa tersebut dijatuhkan pidana penjara. Sehubungan dengan perkara pidana yang dihadapi para pengurus Koperasi Pandawa, beberapa bulan sebelum putusan pidana tersebut, tepatnya pada Mei 2017, Pengadilan Niaga Jakarta Pusat mempailitkan Koperasi Pandawa. Seluruh harta kekayaan Koperasi Pandawa dilelang dan dibagikan ke para kreditur oleh seorang kurator yang telah ditunjuk dalam putusan pailit. Namun, Kejaksaan tidak menerima putusan kepailitan yang menyatakan bahwa segala harta kekayaan Koperasi Pandawa akan diamankan oleh kurator untuk dilakukan pemberesan (pembayaran) kepada para kreditur Koperasi Pandawa. Bertentangan dengan putusan pailit terhadap Koperasi Pandawa, dalam kasus pidana yang divonis belakangan, pengadilan merampas harta Koperasi Pandawa untuk negara.

Tim kurator keberatan dan menggugat vonis pengadilan terkait dengan penyitaan harta kekayaan Koperasi Pandawa itu kembali ke Pengadilan Niaga Jakarta Pusat. Pada September 2018, melalui gugatan dengan perkara No. 11/Pdt.Sus-Gugatan Lainlain/2018/PN.Jkt.Pst yang diajukan tim kurator Koperasi Pandawa dalam mewakili 39.068 nasabah, tim kurator menggugat agar Pemerintah Indonesia (dalam hal ini Kejaksaan RI) mengembalikan harta kekayaan pendiri, pengurus, dan Koperasi Pandawa itu kepada para kreditur secara adil dan berimbang 
(pari passu pro rata parte). Namun atas dasar KUHAP, Kejaksaan tetap mengajukan perlawanan yang pada intinya meminta agar harta Koperasi Pandawa dan harta para pengurusnya menjadi objek sita dalam perkara pidana. Melalui putusan, hakim Pengadilan Negeri Jakarta Pusat mengabulkan gugatan kurator dengan isi putusan adalah 19 aset boedel pailit Koperasi Pandawa menjadi milik penggugat dan pengadilan memerintahkan Kejaksaan menyerahkan barang bukti harta kekayaan pengurus Koperasi Pandawa yang berada dalam penguasaan Kejaksaan kepada tim kurator.

Kejaksaan mengajukan kasasi kepada Mahkamah Agung atas putusan Pengadilan Negeri Jakarta Pusat yang menyatakan bahwa harta Koperasi Pandawa akan diserahkan kepada kurator untuk dilakukan pemberesan pailit. Namun Majelis Hakim Mahkamah Agung dalam putusan Kasasi tidak mengabulkan permohonan kasasi dari Kejaksaan Negeri Depok karena menganggap bahwa Putusan PN Jakarta Pusat No. 11/Pdt.Sus-Gugatan Lainlain/2018/PN.Jkt.Pst yang menyatakan bahwa harta Koperasi Pandawa akan diserahkan kepada kurator untuk dilakukan pemberesan pailit tersebut tidak bertentangan dengan hukum atau undang-undang. Alasan Hakim Mahkamah Agung menolak permohonan Kasasi dari Kejaksaan dinyatakan sebagai berikut:

1. Putusan PN atas perkara No. 37/Pdt.SusPKPU/2017/PN.Niaga.Jkt.Pst yang menyatakan Koperasi Pandawa dan pengurusnya pailit sudah berkekuatan hukum. Dengan demikian atas putusan kasasi ini, maka barang-barang yang dituntut penggugat menjadi boedel pailit akan dibagikan kepada kreditur oleh kurator, karena statusnya sudah pasti bukan milik termohon pailit lagi (Koperasi Pandawa dan pengurusnya); dan

2. Dalam putusan perkara pidana PN Depok No. 424/Pid.Sus/2017/PN.Dpk, No. 425/Pid.Sus/2017/PN.Dpk, No. 426/Pid.Sus/2017/PN.Dpk, No. 427 /Pid.Sus/2017/PN.Dpk, No.
428/Pid.Sus/2017/PN.Dpk, dan No.429/Pid.Sus/2017/PN.Dpk. aset milik Koperasi Pandawa dan pengurusnya adalah sita umum maka tidak bisa dialihkan menjadi milik negara karena bukan milik Koperasi Pandawa dan pengurusnya.

Permasalahan yang dapat diambil dari latar belakang ini adalah timbulnya pertanyaan mengenai mana yang seharusnya lebih didahulukan dalam menguasai harta kekayaan debitor pailit (dhi. Koperasi Pandawa); Kurator dalam proses pemberesan utang kepailitan atau Jaksa/Penuntut Umum dalam proses sita bukti perkara pidana, dan apakah Putusan Pengadilan Negeri Jakarta Pusat No. 11/Pdt.Sus-Gugatan Lainlain/2018/PN.Jkt.Pst dan Putusan Mahkamah Agung RI Putusan Mahkamah Agung Nomor 3 K/Pdt.Sus-Pailit/2019 yang pada intinya lebih mendahulukan penyitaan harta kekayaan debitor palit untuk disita dan dikuasai oleh Kurator guna kepentingan kreditor Koperasi Pandawa dibandingkan dengan penyitaan harta kekayaan tersebut untuk kepentingan perkara pidana, sudah sesuai dengan ketentuan perundang-undangan dan asas hukum yang berlaku di Indonesia. Untuk itu perlu diketahui bagaimana prosedur pemberesan harta pailit (boedel) debitor yang secara bersamaan dikenakan penyitaan barang bukti oleh Kejaksaan/Penuntut Umum untuk keperluan perkara pidana.

\section{Rumusan Masalah}

Berdasarkan latar belakang masalah yang telah diuraikan di atas, maka ditarik rumusan masalah sebagai berikut:

1. Bagaimana prosedur pemberesan harta pailit (boedel) debitor pailit yang secara bersamaan dikenakan penyitaan barang bukti oleh Kejaksaan/Penuntut Umum untuk keperluan perkara pidana?

2. Bagaimana penerapan peraturan perundang-undangan tentang prosedur pemberesan harta pailit (boedel) debitor yang secara bersamaan dikenakan penyitaan barang bukti oleh Kejaksaan/Penuntut Umum pada Putusan Mahkamah Agung Nomor 3 K/Pdt.SusPailit/2019? 


\section{METODE PENELITIAN}

Dalam penelitian ini, Penulis mempergunakan metode penelitian normatif, yaitu dengan menggunakan beberapa peraturan untuk melihat ketentuan dari prosedur pemberesan harta pailit (boedel) debitor yang secara bersamaan dikenakan penyitaan barang bukti oleh Kejaksaan/Penuntut Umum untuk keperluan perkara pidana. Studi putusan pengadilan dalam penelitian ini juga dilakukan untuk mengetahui tolak ukur Majelis Hakim Mahkamah Agung dalam memutuskan Putusan MA No. 3 K/Pdt.Sus-Pailit/2019 yang pada intinya lebih mendahulukan penyitaan harta kekayaan debitor palit untuk disita dan dikuasai oleh Kurator guna kepentingan kreditor Koperasi Pandawa dibandingkan dengan penyitaan harta kekayaan tersebut untuk kepentingan perkara pidana.

Jenis data yang digunakan dalam penelitian ini adalah data sekunder yaitu data yang berasal dari studi kepustakaan, baik literatur hukum, peraturan perundangundangan, maupun bahan-bahan kepustakaan terkait. Untuk menganalisis data dan menarik kesimpulan dari hasil penelitian, kedua bahan hukum yaitu bahan hukum primer dan sekunder dianalisis dengan metode kualitatif untuk selanjutnya disajikan dalam bentuk deskriptif analitis.

\section{HASIL PENELITIAN DAN PEMBAHASAN}

1. Prosedur Pemberesan Harta (Boedel) Debitor Pailit yang Secara Bersamaan Dikenakan Penyitaan Barang Bukti oleh Kejaksaan/Penuntut Umum untuk Keperluan Perkara Pidana

Pada umumnya ketentuan mengenai prosedur pemberesan harta pailit oleh kurator diatur dalam Undang-Undang Kepailitan dan PKPU. Dalam putusan pernyataan pailit, hakim pengadilan negeri dalam perkara tersebut harus menunjuk atau mengangkat Kurator dan Hakim Pengawas dalam rangka pemberesan dan penyelesaian utang terhadap para kreditor, yang merupakan pihak independen dan tidak memiliki benturan kepentingan dengan debitor maupun kreditor.
Sehubungan dengan pentingnya keadilan dalam proses penyelesaian utang bagi para kreditor, UU Kepailitan dan PKPU mengatur mengenai peran andil Kurator dan Hakim Pengawas yang masing-masing memiliki tugas spesifik dalam rangka pengurusan dan penyelesaian utang kepada para kreditor, yang penyelesaiannya (pembayaran) diambil dari harta debitor pailit (boedel). Dalam melakukan tugas ini kurator maupun hakim pengawas memiliki satu visi utama, yaitu mengambil keputusan yang terbaik untuk memaksimalisasikan nilai harta pailit. Tugas Kurator secara umum berdasarkan UU Kepailitan dan PKPU adalah melakukan pengurusan dan/atau pemberesan harta pailit, sedangkan tugas Hakim Pengawas secara umum berdasarkan UU Kepailitan dan PKPU adalah mengawasi pengurusan dan pemberesan harta pailit.

Dalam proses pengurusan dan pemberesan harta pailit, terdapat 3 (tiga) pihak yang saling berkaitan yaitu Hakim Pengawas, Kurator, dan Panitia Kreditor. Proses pemberesan harta pailit setelah diucapkannya putusan pernyataan pailit menurut UU Kepailitan dan PKPU dinyatakan sebagai berikut:

a. Sejak mulai pengangkatannya, Kurator harus melaksanakan semua upaya untuk mengamankan harta pailit dan menyimpan semua surat, dokumen, uang, perhiasan, efek, dan surat berharga lainnya dengan memberikan tanda terima. Yang dimaksud sebagai harta pailit adalah meliputi seluruh kekayaan Debitor pada saat putusan pernyataan pailit diucapkan serta segala sesuatu yang diperoleh selama kepailitan, kecuali harta/aset debitor dalam bentuk, jenis, dan fungsi sebagaimana diatur dalam Pasal 22 UU Kepailitan dan PKPU.

Kurator harus membuat pencatatan harta pailit paling lambat 2 (dua) hari setelah menerima surat putusan pengangkatannya sebagai Kurator, yang mana pencatatan tersebut dapat dilakukan di bawah tangan oleh Kurator dengan persetujuan Hakim Pengawas. Selain itu, anggota panitia kreditor sementara berhak menghadiri pembuatan pencatatan tersebut. Segera setelah dibuat pencatatan harta pailit, 
Kurator harus membuat daftar yang menyatakan sifat, jumlah piutang dan utang harta pailit, nama dan tempat tinggal Kreditor beserta jumlah piutang masingmasing Kreditor.

b. Uang, perhiasan, efek, dan surat berharga lainnya wajib disimpan oleh Kurator sendiri kecuali apabila oleh Hakim Pengawas ditentukan lain. Uang tunai yang tidak diperlukan untuk pengurusan harta pailit, wajib disimpan oleh Kurator di bank untuk kepentingan harta pailit setelah mendapat izin Hakim Pengawas.

c. Paling lambat 14 (empat belas) hari setelah putusan pernyataan pailit diucapkan, Hakim Pengawas harus menetapkan: a) batas akhir pengajuan tagihan; b) batas akhir verifikasi pajak untuk menentukan besarnya kewajiban pajak sesuai dengan peraturan perundang-undangan di bidang perpajakan; dan c) hari, tanggal, waktu, dan tempat rapat Kreditor untuk mengadakan pencocokan piutang. Kurator paling lambat 5 (lima) hari setelah penetapan tersebut, wajib memberitahukan penetapan tersebut kepada semua Kreditor yang alamatnya diketahui dengan surat dan mengumumkannya paling sedikit dalam 2 (dua) surat kabar harian.

d. Semua Kreditor wajib menyerahkan piutangnya masing-masing kepada Kurator disertai perhitungan atau keterangan tertulis lainnya yang menunjukkan sifat dan jumlah piutang, disertai dengan surat bukti atau salinannya, dan suatu pernyataan ada atau tidaknya Kreditor mempunyai suatu hak istimewa, hak gadai, jaminan fidusia, hak tanggungan, hipotek, hak agunan atas kebendaan lainnya, atau hak untuk menahan benda.

e. Kurator wajib mencocokkan perhitungan piutang yang diserahkan oleh Kreditor dengan catatan yang telah dibuat sebelumnya dan keterangan Debitor Pailit; atau berunding dengan Kreditor jika terdapat keberatan terhadap penagihan yang diterima. Kurator berhak meminta kepada Kreditor agar memasukkan surat yang belum diserahkan, termasuk memperlihatkan catatan dan surat bukti asli. Kurator wajib memasukkan piutang yang disetujuinya ke dalam suatu daftar piutang yang sementara diakui, sedangkan piutang yang dibantah termasuk alasannya dimasukkan ke dalam daftar tersendiri.

f. Kurator wajib menyediakan di Kepaniteraan Pengadilan salinan dari masing-masing daftar sebagaimana dimaksud poin e di atas, selama 7 (tujuh) hari sebelum hari pencocokan piutang, dan setiap orang dapat melihatnya secara cumacuma. Kurator wajib memberitahukan dengan surat tentang adanya daftar sebagaimana dimaksud kepada Kreditor yang dikenal, disertai panggilan untuk menghadiri rapat pencocokan piutang dengan menyebutkan rencana perdamaian jika telah diserahkan oleh Debitor Pailit.

g. Rapat pencocokan piutang dilaksanakan dan Debitor Pailit wajib hadir sendiri dalam rapat pencocokan piutang, agar dapat memberikan keterangan yang diminta oleh Hakim Pengawas mengenai sebab musabab kepailitan dan keadaan harta pailit. Kreditor dapat meminta keterangan dari Debitor Pailit mengenai hal-hal yang dikemukakan melalui Hakim Pengawas. Pertanyaan yang diajukan kepada Debitor Pailit dan jawaban yang diberikan olehnya, wajib dicatat dalam berita acara. Dalam rapat, Hakim Pengawas membacakan daftar piutang yang diakui sementara dan daftar piutang yang dibantah oleh Kurator. Setiap Kreditor yang namanya tercantum dalam daftar piutang dapat meminta agar Kurator memberikan keterangan mengenai tiap piutang dan penempatannya dalam daftar, atau dapat membantah kebenaran piutang, adanya hak untuk didahulukan, hak untuk menahan suatu benda, atau dapat menyetujui bantahan Kurator.

h. Piutang yang tidak dibantah wajib dipindahkan ke dalam daftar piutang yang diakui, yang dimasukkan dalam berita acara rapat. Piutang yang oleh Kurator diperintahkan agar dikuatkan dengan sumpah, diterima dengan syarat, sampai saat diterima secara pasti setelah sumpah diucapkan. Berita acara rapat ditandatangani oleh Hakim Pengawas dan panitera pengganti, yang mana pengakuan 
suatu piutang yang dicatat dalam berita acara rapat mempunyai kekuatan hukum yang tetap dalam kepailitan dan pembatalannya tidak dapat dituntut oleh Kurator, kecuali berdasarkan alasan adanya penipuan.

i. Setelah berakhirnya pencocokan piutang, Kurator wajib memberikan laporan mengenai keadaan harta pailit, dan selanjutnya kepada Kreditor wajib diberikan semua keterangan yang diminta oleh mereka. Setelah berakhirnya rapat maka laporan beserta berita acara rapat pencocokan piutang wajib disediakan di Kepaniteraan dan kantor Kurator.

j. Kurator harus memulai pemberesan dan menjual semua harta pailit tanpa perlu memperoleh persetujuan atau bantuan Debitor apabila: usul untuk mengurus perusahaan Debitor tidak diajukan dalam jangka waktu sebagaimana diatur dalam Undang-Undang ini, atau usul tersebut telah diajukan tetapi ditolak; atau pengurusan terhadap perusahaan Debitor dihentikan.

k. Apabila Hakim Pengawas berpendapat terdapat cukup uang tunai, Kurator diperintahkan untuk melakukan pembagian kepada Kreditor yang piutangnya telah dicocokkan. Namun apabila harta debitor pailit tidak mencukupi untuk pembayaran seluruh piutang kreditor yang telah tercatat, maka prosedur, tata cara, dan syarat-syarat pemberesan tersebut mengacu pada Bagian Ketujuh UU Kepailitan dan PKPU.

Dalam uraian mengenai proses pengurusan, pengawasan dan pemberesan harta pailit debitor berdasarkan UU Kepailitan dan PKPU tersebut, tidak dijelaskan dan diatur mengenai kondisi dalam hal terdapat proses sita umum oleh Penuntut Umum untuk keperluan perkara pidana saat proses pemberesan harta kepailitan. Namun, apabila dilihat dari aspek hukum acara pidana, penyitaan atas barang bukti berupa harta debitor dalam perkara kepailitan dapat dilakukan, yang dinyatakan dalam Pasal 39 Undang-Undang Nomor 8 Tahun 1981 tentang Kitab Undang-Undang Hukum Acara Pidana ("KUHAP") sebagai berikut:

"Pasal 39:
(1) Yang dapat dikenakan penyitaan adalah:

a. benda atau tagihan tersangka atau terdakwa yang seluruh atau sebagian diduga diperoleh dari tindakan pidana atau sebagai hasil dari tindak pidana;

b. benda yang telah dipergunakan secara langsung untuk melakukan tindak pidana atau untuk mempersiapkannya;

c. benda yang dipergunakan untuk menghalang-halangi penyidikan tindak pidana;

d. benda yang khusus dibuat atau diperuntukkan melakukan tindak pidana;

e. benda lain yang mempunyai hubungan langsung dengan tindak pidana yang dilakukan.

(2) Benda yang berada dalam sitaan karena perkara perdata atau karena pailit dapat juga disita untuk kepentingan penyidikan, penuntutan dan mengadili perkara pidana, sepanjang memenuhi ketentuan ayat (1)."

Namun KUHAP sendiri tidak mengatur lebih lanjut mengenai prosedur dan bagaimana penyitaan terhadap harta pailit yang sedang dalam penguasaan dan sitaan Kurator dalam perkara kepailitan dapat dilakukan.

Dari aspek hukum kepailitan sebagaimana diatur dalam UU Kepailitan dan PKPU, dalam hal terjadi pembebanan sita umum terhadap objek sita berupa harta kekayaan debitor pailit yang telah dinyatakan pailit berdasarkan putusan Pengadilan Niaga, maka Penuntut Umum pada dasarnya tidak dapat meminta kepada terdakwa atau dalam hal ini pemilik objek sita berupa harta kekayaan debitor pailit untuk menyerahkan harta debitor pailit tersebut. Hal ini didasarkan pada Pasal 24 ayat (1) UU Kepailitan dan PKPU yang menyatakan bahwa "Debitor demi hukum kehilangan haknya untuk menguasai dan mengurus kekayaannya yang termasuk dalam harta pailit, sejak tanggal putusan pernyataan pailit diucapkan". Sejalan dengan ketentuan tersebut, diatur pula bahwa segala tuntutan 
yang berkaitan dengan harta pailit harus ditujukan kepada Kurator, yang diatur sebagai berikut: "Tuntutan mengenai hak atau kewajiban yang menyangkut harta pailit harus diajukan oleh atau terhadap Kurator". Berdasarkan ketentuan-ketentuan ini, maka dalam hal Penuntut Umum dalam suatu perkara pidana bermaksud untuk membebankan sita umum atas objek berupa harta pailit, maka sita tersebut harus diajukan kepada Kurator.

Sita terhadap harta pailit untuk keperluan perkara pidana memang dimungkinkan dan tidak dilarang menurut UU Kepailitan dan PKPU maupun menurut KUHAP. Namun, penyitaan ini tidak dapat dilakukan untuk jenis sita untuk sita negara. Pasal 26 ayat (2) UU Kepailitan dan PKPU menyatakan bahwa:

"Dalam hal tuntutan sebagaimana
dimaksud pada ayat (1) diajukan atau
diteruskan oleh atau terhadap Debitor
Pailit maka apabila tuntutan tersebut
mengakibatkan suatu penghukuman
terhadap Debitor Pailit, penghukuman
tersebut tidak mempunyai akibat hukum
terhadap harta pailit". Berdasarkan ketentuan tersebut dapat dilihat bahwa dalam hal Penuntut Umum
melakukan penuntutan atau proses hukum pidana terhadap debitor pailit, maka tidak akan mempunyai akibat hukum terhadap harta pailitnya.

Ketentuan Pasal 26 ayat (1) UU Kepailitan dan PKPU ini juga sejalan dengan asas keadilan dalam hukum kepailitan. Asas keadilan, yaitu bahwa peraturan kepailitan harus dapat memenuhi rasa keadilan bagi para pihak yang berkepentingan. Menurut Nindyo Pramono, dalam bukunya disebutkan bahwa "dalam kepailitan asas keadilan mengandung pengertian bahwa ketentuan mengenai kepailitan dapat memenuhi keadilan bagi para pihak yang berkepentingan. Asas keadilan ini untuk mencegah terjadinya kesewenangwenangan pihak penagih yang mengusahakan pembayaran atas tagihan masing-masing terhadap debitur, dengan tidak memperdulikan kreditor lainnya". Asas keadilan ini juga dapat diterapkan dalam konteks penyitaan harta debitor pailit pada perkara pidana, dimana penyitaan oleh Penuntut Umum dalam perkara pidana tidak boleh menimbulkan akibat hukum yang memberikan ketidakadilan bagi para pihak yang berkepentingan yang dalam hal ini merupakan kreditor dari debitor pailit itu sendiri.

Dengan demikian penulis sampai pada konklusi dimana pada dasarnya UU Kepailitan dan PKPU memang tidak mengatur secara eksplisit mengenai prosedur penyitaan terhadap harta pailit oleh Penuntut Umum dalam hal terdapat perkara pidana yang berjalan bersamaan, namun UU Kepailitan dan PKPU memberikan kemungkinan untuk dapat dilakukannya penggunaan harta pailit untuk kepentingan pidana dengan batasan bahwa harta pailit tersebut tetap dapat diproses secara kepailitan untuk dimanfaatkan Kurator dalam melakukan pemberesan piutang para kreditor, sebagai tujuan dari mekanisme kepailitan itu sendiri. Penggunaan atau campur tangan penegak hukum pada perkara pidana terhadap harta pailit juga harus mementingkan kepentingan yang lebih luas seperti kepentingan kreditor dan masyarakat luas dan bukan hanya sekedar menjalankan ketentuan yang diperbolehkan dalam KUHAP, agar asas keadilan dalam hukum kepailitan dapat diterapkan dan diwujudkan untuk kepentingan masyarakat.

2. Penerapan peraturan perundang. undangan tentang prosedur pemberesan harta pailit (boedel) debitor yang secara bersamaan dikenakan penyitaan barang bukti oleh Kejaksaan/Penuntut Umum pada Putusan Mahkamah Agung Nomor 3 K/Pdt.Sus-Pailit/2019

Majelis Hakim Mahkamah Agung dalam Putusan Kasasi No. 3 K/Pdt.Sus-Pailit/2019 pada intinya memutus tidak mengabulkan permohonan kasasi dari Kejaksaan Negeri Depok karena menganggap bahwa Putusan PN Jakarta Pusat No. 11/Pdt.Sus-Gugatan Lainlain/2018/PN.Jkt.Pst yang menyatakan bahwa harta Koperasi Pandawa akan diserahkan kepada kurator untuk dilakukan pemberesan pailit tersebut tidak bertentangan dengan hukum atau undang-undang. Alasan Hakim Mahkamah Agung menolak permohonan 
Kasasi dari Kejaksaan dinyatakan sebagai berikut:

1. Putusan PN atas perkara No. 37/Pdt.SusPKPU/2017/PN.Niaga.Jkt.Pst yang menyatakan Koperasi Pandawa dan pengurusnya pailit sudah berkekuatan hukum. Dengan demikian atas putusan kasasi ini, maka barang-barang yang dituntut penggugat menjadi boedel pailit akan dibagikan kepada kreditur oleh kurator, karena statusnya sudah pasti bukan milik termohon pailit lagi (Koperasi Pandawa dan pengurusnya); dan

2. Dalam putusan perkara pidana PN Depok No. 424/Pid.Sus/2017/PN.Dpk, No. 425/Pid.Sus/2017/PN.Dpk, No. 426/Pid.Sus/2017/PN.Dpk, No. 427 /Pid.Sus/2017/PN.Dpk, $\quad$ No. 428/Pid.Sus/2017/PN.Dpk, dan No.429/Pid.Sus/2017/PN.Dpk. saat diputus, aset milik Koperasi Pandawa dan pengurusnya sudah diputus sita umum sebagaimana Pasal 31 ayat (1) UU Kepailitan dan PKPU, sehingga tidak bisa dialihkan menjadi milik negara karena bukan milik Koperasi Pandawa dan pengurusnya lagi.

Menurut Penulis, pertimbangan Majelis Hakim Mahkamah Agung dalam Putusan Kasasi No. 3 K/Pdt.Sus-Pailit/2019 ini telah sesuai dengan ketentuan dalam UU Kepailitan dan PKPU. Pertimbangan sebagaimana diuraikan dalam Poin 1 di atas yang mana harta pailit Koperasi Pandawa telah menjadi harta (boedel) pailit yang akan dibagikan kepada kreditor oleh Kurator telah sesuai dengan ketentuan Pasal 1 angka 1, Pasal 21, Pasal 24 ayat (1), Pasal 26 ayat (1), dan Pasal 69 ayat (1) UU Kepailitan dan PKPU yang menyatakan bahwa:

Pasal 1 angka 1: "Kepailitan adalah sita umum atas semua kekayaan Debitor Pailit yang pengurusan dan pemberesannya dilakukan oleh Kurator di bawah pengawasan Hakim Pengawas sebagaimana diatur dalam UndangUndang ini.",

Pasal 21: "Kepailitan meliputi seluruh kekayaan Debitor pada saat putusan pernyataan pailit diucapkan serta segala sesuatu yang diperoleh selama kepailitan.";

Pasal 24 ayat (1): "Debitor demi hukum kehilangan haknya untuk menguasai dan mengurus kekayaannya yang termasuk dalam harta pailit, sejak tanggal putusan pernyataan pailit diucapkan";

Pasal 26 ayat (1): "Tuntutan mengenai hak atau kewajiban yang menyangkut harta pailit harus diajukan oleh atau terhadap Kurator.";

Pasal 69 ayat (1): "Tugas Kurator adalah melakukan pengurusan dan/atau pemberesan harta pailit.".

Berdasarkan ketentuan-ketentuan di atas, pada intinya sejak putusan pailit diucapkan semua wewenang debitor untuk menguasai dan mengurus harta pailit beralih kepada kurator. Dengan demikian dalam hal Penuntut Umum dalam proses perkara pidana bermaksud untuk menggunakan, menyita, atau menguasai harta kekayaan Koperasi Pandawa selaku debitor yang sudah dinyatakan pailit berdasarkan Putusan No. 37/Pdt.SusPKPU/2017/PN.Niaga.Jkt.Pst, maka permintaan tersebut harus dilakukan kepada Kurator selaku pemilik kuasa atas harta dari Koperasi Pandawa. Namun, mengingat harta Koperasi Pandawa akan digunakan untuk pemberesan piutang para kreditor, maka Penuntut Umum dalam perkara pidana tidak dapat melakukan hal-hal yang berakibat hukum bagi harta kekayaan Koperasi Pandawa, termasuk melakukan sita untuk negara untuk seluruh atau sebagian dari harta/aset Koperasi Pandawa tersebut.

Selain itu, terhadap pertimbangan Majelis Hakim Mahkamah Agung dalam Putusan Kasasi No. 3 K/Pdt.Sus-Pailit/2019 sebagaimana telah diuraikan dalam Poin 2 di atas juga telah sesuai dengan ketentuan dalam UU Kepailitan dan PKPU. Putusan perkara pidana PN Depok No. 424/Pid.Sus/2017/PN.Dpk, No. 425/Pid.Sus/2017/PN.Dpk, No. 426/Pid.Sus/2017/PN.Dpk, $\quad$ No. 427 /Pid.Sus/2017/PN.Dpk, No. 428/Pid.Sus/2017/PN.Dpk, dan No.429/Pid.Sus/2017/PN.Dpk. yang pada 
amar ketiga memutus untuk melakukan sita umum untuk negara terhadap harta/aset dari Koperasi Pandawa merupakan putusan yang salah dan harus dibatalkan karena melanggar ketentuan Pasal 31 ayat (1) UU Kepailitan dan PKPU yang berbunyi: "Putusan pernyataan pailit berakibat bahwa segala penetapan pelaksanaan Pengadilan terhadap setiap bagian dari kekayaan Debitor yang telah dimulai sebelum kepailitan, harus dihentikan seketika dan sejak itu tidak ada suatu putusan yang dapat dilaksanakan termasuk atau juga dengan menyandera Debitor". Sehingga Penuntut Umum pada dasarnya tidak dapat menuntut penyitaan terhadap harta kekayaan/aset Koperasi Pandawa karena putusan pailit No. 37/Pdt.SusPKPU/2017/PN.Niaga.Jkt.Pst telah terlebih dahulu diputus dan memiliki kekuatan hukum daripada putusan perkara pidananya.

\section{SIMPULAN}

Berdasarkan pembahasan yang telah diuraikan sebelumnya, dapat diambil kesimpulan bahwa ketentuan hukum kepailitan sebagaimana diatur dalam UU Kepailitan dan PKPU maupun ketentuan hukum acara pidana sebagaimana diatur dalam KUHAP belum memiliki ketentuan mengenai prosedur yang diatur secara eksplisit dan konkrit, dalam hal terjadi kondisi dimana harta debitor pailit dalam proses kepailitan menjadi objek sita oleh dalam perkara pidana di waktu yang bersamaan. Namun, UU Kepailitan dan PKPU memberikan kemungkinan untuk dapat dilakukannya penggunaan harta pailit untuk keperluan perkara pidana, dengan batasan penggunaan tersebut tidak boleh memiliki akibat hukum apapun terhadap harta kekayaan debitor pailit. Hal ini dikarenakan harta kekayaan debitor pailit merupakan aspek yang krusial dan fundamental untuk proses kepailitan itu sendiri, yang akan digunakan untuk mencapai dan mewujudkan asas keadilan dalam hukum kepailitan, yang dalam hal ini adalah untuk kepentingan dan manfaat bagi para kreditor.

Putusan dan pertimbangan Majelis Hakim Mahkamah Agung berdasarkan putusan No. 3 K/Pdt.Sus-Pailit/2019 telah sesuai dengan ketentuan mengenai prosedur pemberesan harta pailit sebagaimana diatur dalam UU Kepailitan. Putusan tersebut telah merepresentasikan asas keadilan dalam hukum kepailitan dengan berpendapat bahwa harta kekayaan Koperasi Pandawa itu sendiri akan lebih manfaat apabila dipergunakan sesuai dengan kegunaannya berdasarkan UU Kepailitan dan PKPU, yaitu untuk menyelesaikan piutang kreditor.

\section{DAFTAR PUSTAKA \\ Buku:}

Pramono, Nindyo dan Sularto. Hukum Kepailitan dan Keadilan Pancasila. Yogyakarta: Penerbit Andi, 2017.

Pramono, Nindyo. Hukum Kepailitan 2: Himpunan Materi Kuliah Magister Hukum Bisnis. Yogyakarta: FH UGM, 2012.

Purwosutjipto, H.M.N. Perwasitan, Kepailitan, dan Penundaan Pembayaran. Jakarta: Djambatan, 1988. Puslitbang Hukum dan Peradilan Badan Litbang Diklat Kumdil, Mahkamah Agung Republik Indonesia. Laporan Penelitian: Penerapan Asas Solvabilitas dalam Penyelesaian Perkara Kepailitan. Jakarta: Mahkamah Agung Republik Indonesia, 2014.

\section{Peraturan Perundang-undangan:}

Indonesia. Kitab Undang-Undang Hukum Pidana, UU No. 8 Tahun 1981, LN No. 76 Tahun 1981, TLN No. 3258.

Indonesia. Undang-Undang Kepailitan dan Penundaan Kewajiban Pembayaran Utang, UU No. 37 Tahun 2004, LN No. 131 Tahun 2004, TLN No. 4443.

\section{Putusan Pengadilan:}

Pengadilan Negeri Jakarta Pusat. Putusan No. 37/Pdt.Sus-

PKPU/2017/PN.Niaga.Jkt.Pst.

Pengadilan Negeri Jakarta Pusat. Putusan No. 11/Pdt.Sus-Gugatan Lainlain/2018/PN.Jkt.Pst.

Mahkamah Agung Republik Indonesia. Putusan No. 3K/Pdt.Sus-Pailit/2019.

\section{Internet:}

Kurnia, Abi Jam'an. "Tugas-Tugas Kurator dan Hakim Pengawas" 
Jurnal Ilmu Sosial dan Pendidikan

Vol. 5. No. 2 Maret 2021

http://ejournal.mandalanursa.org/index.php/JISIP/index

Terakreditasi Peringkat 5 (No. SK: 85/M/KPT/2020)

https://www.hukumonline.com/klinik/d etail/ulasan/cl738/tugas-tugas-kurator-

dan-hakim-pengawas/

Malau, Budi Sam Law. "Baru Satu Nasabah

Pandawa Melapor ke Polisi"

https://wartakota.tribunnews.com/2017/

01/19/baru-satu-nasabah-pandawa-

melapor-ke-polisi

Saputra, Andi. "Babak Baru Sengketa Aset Koperasi Pandawa Rp 3,3 Triliun" https://news.detik.com/berita/d-

4534163/babak-baru-sengketa-aset-

koperasi-pandawa-rp-33-triliun

Sari, Deliana Pradhita. "Bos Koperasi

Pandawa Nuryanto Divonis 15 Tahun

Penjara"

https://kabar24.bisnis.com/read/201712

11/16/717182/bos-koperasi-pandawa-

nuryanto-divonis-15-tahun-penjara

Viodeogo, Yanuarius. "Kasus Koperasi Pandawa : MA Tolak Kasasi Kejari Depok, Aset Diserahkan ke Kurator" https://kabar24.bisnis.com/read/201905 06/16/918943/kasus-koperasi-pandawama-tolak-kasasi-kejari-depok-aset-

diserahkan-ke-kurator. 